\title{
Forecasting South Africa's performance at the 2010 Commonwealth Games
}

\author{
Girish M Ramchandani (MSc) \\ Darryl J Wilson (MSc) \\ Sport Industry Research Centre, Sheffield Hallam University, Sheffield, UK
}

\begin{abstract}
Objectives. This paper predicts South Africa's performance at the Delhi 2010 Commonwealth Games.

Methods. Potential scenarios are developed based on South Africa's previous performances.

Results. South Africa will win up to 15 gold medals and 43 medals in total.

Conclusions. After Delhi 2010, the actual results should be examined to verify the forecasts.
\end{abstract}

\section{Introduction}

The purpose of this paper is to make an informed forecast of how South Africa will perform at the 2010 Commonwealth Games to be held in Delhi, India, between 3 and 14 October. The forecast is expressed in terms of the number of gold medals and total medals that South African athletes can expect to win at Delhi 2010.

Forecasting performance in elite sports competitions is not a new phenomenon. Traditionally, prediction models have tended to focus almost exclusively on the Olympic Games. ${ }^{1-5}$ More recent studies have sought to predict the performance of nations that previously hosted, or are scheduled to host, the Summer Olympic Games. ${ }^{3-5}$ In this context, this paper provides a departure from normal convention by attempting to forecast how a nation will perform away from home in the Commonwealth Games.

\section{CORRESPONDENCE:}

Girish M Ramchandani

Sport Industry Research Centre

Sheffield Hallam University

A118 Collegiate Hall

Collegiate Crescent

Sheffield S10 2BP

UK

Tel: +44 (0) 1142255461

E-mail: g.ramchandani@shu.ac.uk

\section{Methods}

The approach used to forecast South Africa's performance in Delhi in 2010 was to examine and interpret the nation's results in previous editions of the Commonwealth Games. The historical results for South Africa were collated from the Commonwealth Games Federation website (http://www.thecgf.com, last accessed 15 March 2010). The data were formatted in a spreadsheet and analysed to develop three potential scenarios, as illustrated below.

Scenario 1 models South Africa's likely performance in 2010 on a sport-by-sport basis in accordance with the proportion of medals it achieved in the most recent edition of the Commonwealth Games (Melbourne 2006), while allowing for a change in the number of events that will be contested in each sport in Delhi.

In Scenario 2 we calculate how many medals South Africa will win in Delhi if its performance in each sport follows the same pattern of growth since South Africa rejoined the Commonwealth in 1994. Since then there have been four editions of the Commonwealth Games, even though the analysis focuses on the last three editions (1998 - 2006) because some of the sports to be contested in Delhi were not introduced to the Commonwealth Games programme until 1998.

Recent research ${ }^{6}$ indicates that, as a general rule of thumb, a nation's performance in the Commonwealth Games is negatively correlated with travel (as measured by the number of time zones crossed). In other words, as distance travelled increases, performance deteriorates.

Therefore, Scenario 3 considers South Africa's performance since 1998 with regard to how many time zones its athletes had to traverse to reach the host destination. For sports where travel was found to have a detrimental impact on the performance of South African athletes, the forecast was adjusted to model the potential outcome of the Commonwealth Games being held in India (time zone: UTC + 05:30).

\section{Results}

The results for each scenario are summarised in Table I.

Scenario 1. In this scenario, South Africa can expect to win 12 gold medals and 40 medals in total at Delhi 2010. In absolute terms, South Africa will win the same number of gold medals as in Melbourne in 2006, but will win two extra medals overall. This reflects the fact that more events will be contested at Delhi 2010 (257) than at Melbourne 2006 (245); however, in 2010 there are 11 fewer events in the two sports in which South Africa enjoyed the most success in 2006 - athletics and swimming. Collectively, these sports accounted for $83 \%(10 / 12)$ of gold medals and $68 \%(26 / 38)$ of all medals won by South Africa at Melbourne 2006. 


\section{Table I. Forecasts of South Africa's performance at Delhi 2010}

\begin{tabular}{|c|c|c|c|c|c|c|c|c|}
\hline \multirow[b]{2}{*}{ Sport } & \multicolumn{2}{|c|}{$\begin{array}{c}\text { Delhi } 2010 \text { medals } \\
\text { available }\end{array}$} & \multicolumn{2}{|c|}{$\begin{array}{l}\text { SA forecast - } \\
\text { scenario } 1\end{array}$} & \multicolumn{2}{|c|}{$\begin{array}{l}\text { SA forecast - } \\
\text { scenario } 2\end{array}$} & \multicolumn{2}{|c|}{$\begin{array}{l}\text { SA forecast - } \\
\text { scenario } 3\end{array}$} \\
\hline & $\begin{array}{l}\text { Gold } \\
\text { medals }\end{array}$ & $\begin{array}{l}\text { Total } \\
\text { medals }\end{array}$ & $\begin{array}{l}\text { Gold } \\
\text { medals }\end{array}$ & $\begin{array}{l}\text { Total } \\
\text { medals }\end{array}$ & $\begin{array}{l}\text { Gold } \\
\text { medals }\end{array}$ & $\begin{array}{l}\text { Total } \\
\text { medals }\end{array}$ & $\begin{array}{l}\text { Gold } \\
\text { medals }\end{array}$ & $\begin{array}{l}\text { Total } \\
\text { medals }\end{array}$ \\
\hline Athletics & 46 & 138 & 4 & 12 & 5 & 11 & 5 & 11 \\
\hline Badminton & 6 & 18 & - & - & - & - & - & - \\
\hline Boxing & 10 & 40 & 1 & 2 & 1 & 3 & 1 & 2 \\
\hline Cycling & 18 & 54 & - & 1 & - & - & - & - \\
\hline Diving & 10 & 30 & - & - & - & - & - & - \\
\hline Gymnastics & 20 & 60 & - & 1 & - & - & - & - \\
\hline Hockey & 2 & 6 & - & - & - & - & - & - \\
\hline Lawn bowls & 6 & 18 & - & 2 & - & 1 & 1 & 3 \\
\hline Netball & 1 & 3 & - & - & - & - & - & - \\
\hline Rugby 7s & 1 & 3 & - & - & - & - & - & 1 \\
\hline Shooting & 36 & 108 & 1 & 5 & - & 4 & - & 9 \\
\hline Squash & 5 & 15 & - & - & - & - & - & - \\
\hline Swimming & 40 & 120 & 5 & 11 & 7 & 17 & 7 & 11 \\
\hline Table tennis & 7 & 21 & - & - & - & - & - & - \\
\hline Weightlifting & 15 & 45 & - & 1 & - & 1 & - & 1 \\
\hline Wrestling * & 21 & 63 & - & 3 & - & 3 & - & 3 \\
\hline Subtotal & 244 & 742 & 11 & 38 & 13 & 40 & 14 & 41 \\
\hline Other $^{\dagger}$ & 13 & 39 & 1 & 2 & 1 & 2 & 1 & 2 \\
\hline Total & 257 & 781 & 12 & 40 & 14 & 42 & 15 & 43 \\
\hline \multicolumn{9}{|c|}{$\begin{array}{l}\text { †Includes archery and tennis, for which no recent relevant performance data are available. Archery was held only once in } 1982 \text { and tennis will make its debut at } \\
\text { Delhi 2010. The forecasts for these sports are made proportionately according to the ratio of gold medals and total medals that South Africa can expect to win in the conventional } \\
\text { sports. }\end{array}$} \\
\hline
\end{tabular}

Scenario 2. By regressing South Africa's performance (medals won divided by medals available) in the Commonwealth Games over time (1998 - 2006) and extrapolating to 2010, the forecast for Delhi is 14 gold medals and 42 total medals. The scenario 2 forecast is more favourable than the scenario 1 forecast, largely because South Africa's performance in swimming has been on an upward trend since 1998.

Scenario 3. If we factor in the relative influence of travel on performance then South Africa can be expected to win 15 gold medals and 43 medals overall at Delhi 2010, despite fewer numbers of medals available in key sports. Therefore, this scenario offers the most optimistic view of anticipated performance. Gains are likely to be made in lawn bowls, shooting and rugby sevens.

\section{Conclusions}

The quality of any forecasting model is only as good as the assumptions that underpin it. In this paper, we have considered three different scenarios to model how many medals South Africa will win at the Delhi 2010 Commonwealth Games based on its performance in recent editions. The analysis reveals that South Africa can expect to win 12 - 15 gold medals and 40 - 43 medals in total. The scenarios offer distinct forecasts of how South Africa will perform in Delhi, but broadly agree on the number of medals it can be expected to win. It would be worthwhile to scrutinise the actual performance of South African athletes in Delhi to test the accuracy of the forecasts presented in this paper.

\section{REFERENCES}

1. Bernard A, Busse M. Who wins the Olympic Games? Economic resources and medal totals. Review of Economics and Statistics 2004; 6(1):413417.

2. Bian X. Predicting Olympic medal counts: The effects of economic development on Olympic performance. The Park Place Economist 2005;XIII:37-44.

3. Clarke SR. Home advantage in the Olympic Games. In: Cohen G, Lantrey T, eds. Proceedings of the Fifth Australian Conference on Mathematics and Computers in Sport. Sydney, NSW: University of Technology Sydney, 2000:43-51.

4. Shibli S, Bingham J. A forecast of the performance of China in the Beijing Olympic Games 2008 and the underlying performance management issues. Managing Leisure 2008;13:272-292.

5. Nevill AM, Balmer NJ, Winter EM. Why Great Britain's success in Beijing could have been anticipated and why it should continue beyond 2012. $\mathrm{Br}$ J Sports Med 2009;43:1108-1110.

6. Ramchandani G, Wilson D. Home advantage in the Commonwealth Games South African Journal of Sports Medicine 2010;22:8-11. 